\title{
Histological aberrations and mode of damage of cowpea (Vigna unguiculata) by Colletotrichum destructivum
}

\author{
DAVID NWAZUO ENYIUKWU*, ANDERSON CHIDI AMADIOHA, CHARLES CHIMEZIE ONONUJU \\ Department of Plant Health Management, Michael Okpara University of Agriculture. Umudike Km 10, Umuahia-Ikot-ekene Road, PMB 7267 Umuahia, \\ Abia State, Nigeria. Tel.: +234-9092309790, "email: enyidave2003@ gmail.com
}

Manuscript received: 11 October 2020. Revision accepted: 28 December 2020.

\begin{abstract}
Enyiukwu DN, Amadioha AC, Ononuju CC. 2021. Histological aberrations and mode of damage of cowpea (Vigna unguiculata) by Colletotrichum destructivum. Nusantara Bioscience 13: 16-23. Leaf and stem of healthy 2-week old cowpea (Vigna unguiculata L. Walp.) seedlings were inoculated with spore suspension of the Colletotrichum destructivum O'Gara. Sections of the infection courts were prepared and examined under digital microscope. The results showed that the infection process began 12 hours after inoculation (hai) with the germination of spores of the fungus. Large multi-lobed primary hypha (somewhat spherical in shape) developed from the infection peg and remained inside a single epithelial cell for about 3 days. Towards the end of this time, the primary hyphae developed thin filamentous tentacles that punctured and branched into adjoining cells, initiating necrotrophic phase of the disease. During this period, typical anthracnose symptoms began to develop on the infected organs of the crop. The entire infection process lasted a maximum of $96 \mathrm{~h}$, at the end of which acervulus that bore a single seta emerged on infected crop lesions. The mechanism of damage of the pathogen involved intra-cellular and inter-cellular colonization of the host tissues early and late in the disease cycle. The integrity of the affected tissues' cells was compromised by passage and colonization of Colletotrichum destructivum O'Gara evidenced by lack of clear-cut middle lamella and cell boundaries. Anthracnose affected cells dispossessed of vital nutrients became turbid, devoid of turgidity and vigor. Thus, these results have strong implications for plant health management in that effective environment-compliant control of the fungus should be initiated on or before the third day following arrival of the conidia of the pathogen on the crop. Seeds are major agents of introduction of Colletotrichum spp. to disease-free locations. Findings from this study also support that strong trans-border control of seeds of the crop should be maintained since the pathogen is known to be seed-borne and demonstrates sufficient cross-infection of crop plants.
\end{abstract}

Keywords: Anthracnose, Colletotrichum destructivum, cowpea, hemibiotrophy, hyphal colonization

\section{INTRODUCTION}

The place of legumes especially cowpea (sometimes called southern pea) (Vigna unguiculata L. Walp.) (Figure 1.A) in the nutrition of the third world cannot be overemphasized. The crop serves as both vegetable and pulse crop. It remains a major provider of proteins, amino acids, essential vitamins, and minerals in many meat-scarce locations of tropical third worlds (Enyiukwu et al. 2018; Falade et al. 2018). Though the crop is important as biofertilizer in farming systems and a source of valuable amino acids in human nutrition, however, economic production of this important legume is deeply constrained by arthropod pests and pathogenic diseases; amongst which anthracnose (Figure 1.B) is major (Adegbite and Amusa 2008; Akinbode and Ikotun 2008a,b).

Colletotrichum species are underscored as causal agents of anthracnose which are commonly associated with various tropical and sub-tropical legumes in both field and storage (Begum et al. 2007; 2013). Colletotrichum spp. are ranked amongst the top 10 most damaging plant pathogens on a world scale; causing large scale economic losses in the production, shelf life and marketing chains of agro-produce including solanum and legumes (Sharma et al. 2017; Coates et al. 2019; Guarnaccia et al. 2019; Xie et al. 2019) In China, India, Brazil, Uganda, South Africa, Ethiopia,
Nigeria and various parts of Asia C. gloeosporioides, $C$. fragerie, $C$. dermatium, $C$. lindemuthianum and $C$. destructivum have been reported to be associated with anthracnose in cowpea (Enyiukwu 2017). In Nigeria, $C$. lindemuthianum and $C$. destructivum have been advanced as cause of anthracnose of the crop in the country; however, extensive molecular evaluations of many accessions of both pathogens have conclusively upheld the later as solely responsible for the disease in the crop (Latunde-Dada et al. 1996; 1997; Adegbite and Amusa 2008; Akinbode and Ikotun 2008a,b; ASHC 2015). Besides cowpea, curly dock, angula (Eruca sativa), tobacco, lucerne, alfalfa, Arabidopsis thaliana, and dodder are affected by anthracnose due to members of Colletotrichum destructivum sensu lato (Lee and Kim 2001; Patel et al. 2014; Enyiukwu et al. 2014; Da Silva 2017). Though Colletotrichum spp are host-specific, cross-infection of hosts has been reported in the genera (Coates et al. 2019).

During no crop seasons, $C$. destructivum overwinters in the seed coats, cotyledons, crop thrash, or related crop debris until the next cropping season (Enyiukwu and Awurum 2013a; Enyiukwu et al. 2014; Guarnaccia et al. 2019). Under warm temperatures $\left(27-28^{\circ} \mathrm{C}\right.$ especially at night), prolonged moist conditions or free moisture on susceptible host surfaces or soils (lasting 24-48 h); spores of the fungus germinate to initiate the disease on the crop 
(Miles et al. 2013; Enyiukwu and Awurum 2013b; Falade et al. 2018). Dark, depressed, irregularly shaped, watersoaked lesions develop on affected host stems, branches, petioles, and lamina (Figure 1.B) which coalesce rapidly to girdle plant (Coates et al. 2019). In Nigeria, incidence and yield losses as high as $83 \%$ and 50-100\% respectively have been ascribed to moderate to severe attacks of anthracnose disease on cowpea accessions grown in different agro-ecological zones of the country (Awurum 2013; Enyiukwu et al. 2014).

In their relationships with host crops, Colletotrichum species exhibit endophytic, latent, necrotrophic, and hemibiotrophic lifestyles; however, hemibiotrophy is the most common life-strategy (Smith et al. 1999; Da Silva et al. 2017). Hemibiotrophy is sub-categorized into subcuticular intramural strategy which is common in $C$. capsici and amongst some pathogens in $C$. gloeosporioides clade; and intracellular hemibiotrophic lifestyle which characterizes $C$. destructivum sensu lato (Enyiukwu et al. 2014; Da Silva et al. 2017). C. destructivum and related species live intracellular hemibiotrophic lifestyle (LatundeDada et al. 1996; 1997; 1999). The successes of Colletotrichum spp. in the colonization of susceptible hosts and initiating anthracnose disease is reported to depend among other variables on their ability to elaborate specialized infection structures from their conidia such as appressoria and infection pegs on target tissues (Amadioha 1994; Tucker and Talbot 2001; Damm et al. 2009; 2014). In the case of Colletotrichum destructivum sensu lato; the infection peg penetrates the host cuticle mechanically, forms the primary hypha by which it establishes short-lived biotrophic lifestyle in a single epidermal cell which lasts between 48-72 h post-inoculation (Shen et al. 2001; Da Silva et al. 2017). After this time, the pathogen graduates to a damaging enzymes-assisted necrotrophic relationship characterized by extensive development of thin secondary hlyphae into adjoining cells, and emergence of anthracnose symptoms (depressed dark tan lesion with black acervuli) on the crop (Latunde-Dada et al. 1996; 1999). The lesions of the disease on the crop (Figure 1.B) stems from anatomical aberrations as the fungus wades through and breaks down host's tissues; causing reduction in photosynthetic area, lowering photosynthetic rate; reduction of total chlorophyll occasioned by toxic metabolites from the fungus; and depletion of essential nutrients and vital electrolytes (Meyer et al. 2001; Lobato et al. 2014; Markson et al. 2014). Besides, in stem infections, the fungus compromises interlocking cross walls responsible for strength and rigidity of stems and branches leading to tipping over and collapse of seedlings (Amadioha and Enyiukwu 2019a,b).

In affected cowpeas, substantial leakage of electrolytes, loss of vital nutrients such as proteins, carbohydrates lipids, crude fiber, calcium, and phosphorus from the crop; and a general reduction of quality of their products have been reported (Begum et al. 2008; 2013). In several field and storage evaluations, average loss of proximate and elemental nutrients ranging between 20 to $30 \%$ attend the interaction of susceptible varieties of cowpea with the pathogen within 1 month period (Amadioha and Enyiukwu 2019a,b). Parallel evaluations of the effects of related fungi on yams, sweet and Irish potatoes revealed a nutrient loss profile of 30-60\% during the 3-6 months storage period (Markson et al. 2014). C. destructivum and other crop decimating fungi utilize host-derived proteins, electrolytes, and metabolites to support their own growth, accumulate biomass and generate energy (Strivastava et al. 2013; Amadioha and Enyiukwu 2019a, b). Smith et al. (1999) and Latunde-Dada et al. (1999) noted that infection process of Colletotrichum species is attended by distortions in the anatomy and physiology of the susceptible crop cultivar.
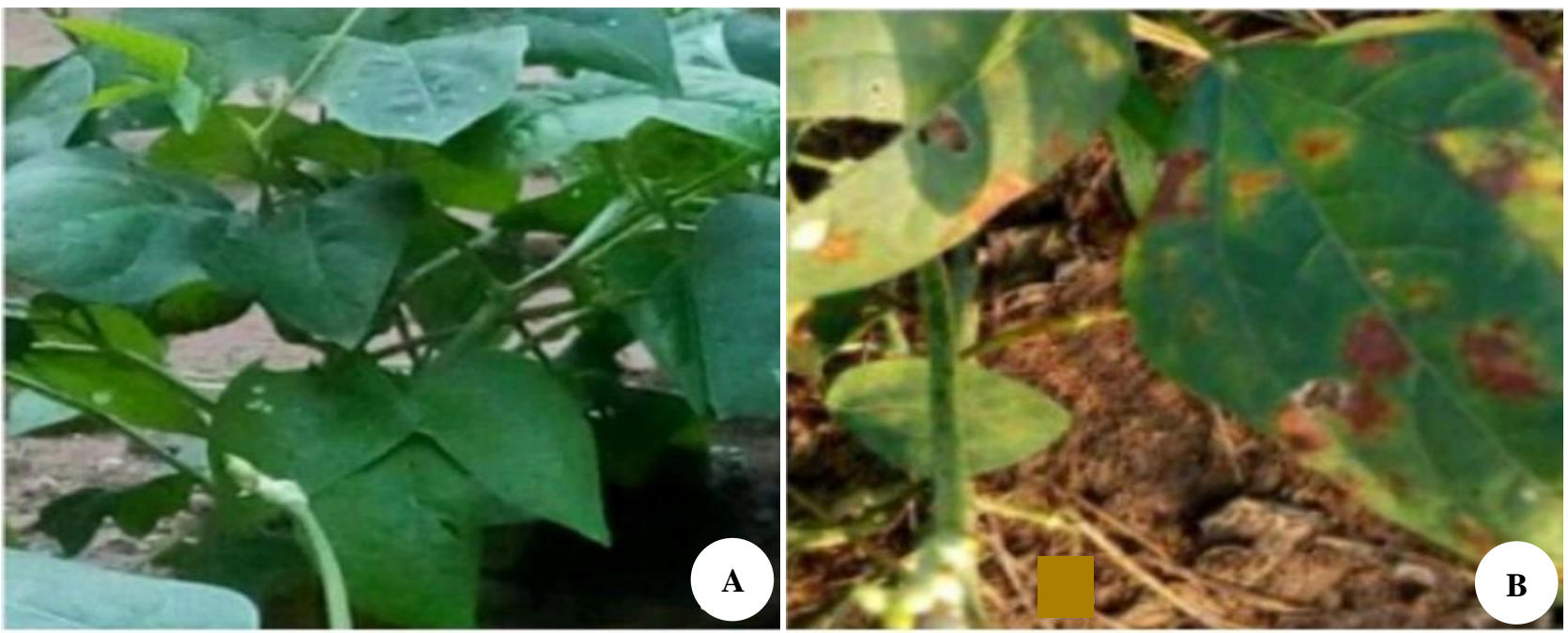

Figure 1. Cowpea (Var. IAR-48) growing in the field. A. Healthy (uninfected) cowpea. B. Anthracnose infected cowpea showing darktan irregular lesions on leaf of the crop 
Though the identity and infection process of cowpea anthracnose pathogens have been studied in South Africa on one hand and Southwestern Nigeria on the other; however, no similar studies have been conducted on the crop in Southeast region of Nigeria. So far, therefore, information on the infection process and extent of damage to cowpea tissues by $C$. destructivum and its synonyms during infection and colonization in the area is to the best of our knowledge non-existent. Against the backdrop of the huge loss profile on the biological and economic yields of the crop due to the disease; therefore, this work was undertaken to study the infection process and determine the extent of anatomical damage done to stem and leaf tissues of cowpea by $C$. destructivum during infection and colonization of the crop in the humid Umudike, Southeast, Nigeria.

\section{MATERIALS AND METHODS}

\section{Experimental site}

The experiment was conducted at the Crop Science Laboratory and greenhouse of the Department of Plant Health Management, College of Crop and Soil Sciences as well as the Microbiology Laboratory of the College of Veterinary Medicine; all of the Michael Okpara University of Agriculture, Umudike, Abia State. The University is located at latitude $5^{\circ} 29^{1} \mathrm{~N}$, longitude $7^{\circ} 33^{1} \mathrm{E}$, and an altitude of 121.08 meters above sea level (GPS Coordinates 2017).

\section{In vitro experiment}

Isolation and identification of the causal agent

Pods of infected cowpea (Vigna unguiculata (L.) Walp) with typical symptoms of anthracnose were collected from the University Research Farm. The pods were cut in bits using a surgical blade, sterilized in $70 \%$ ethanol and finally washed in several changes of $200 \mathrm{ml}$ of sterile distilled water. The tissues were placed in Petri dishes containing moistened Whatman No 1 filter paper, and incubated for 7 days at $27^{\circ} \mathrm{C}$. Then $39.50 \mathrm{~g}$ of dehydrated potato dextrose agar (PDA) (Oxoid® ThermoScientific Product, England, UK) was dissolved in $1000 \mathrm{ml}$ of sterile distilled water in a $2 \mathrm{~L}$ flask, stirred thoroughly with a glass stirrer, then stoppered and autoclaved at 15 Psi for 30 minutes. The mycelial growth from the plated tissues was repeatedly sub-cultured to obtain the pure culture of the organism maintained on PDA as prepared above. The isolate was subjected to pathogenicity tests by reinoculating it into 2-week old cowpea seedlings. About 4 days after inoculation of the seedlings, typical anthracnose symptoms resembling those observed on the diseased pods were observed on the leaf blades and petioles of the seedlings (Ogu and Owoeye 2013; Markson et al. 2014). Thus, confirming that the organism is pathogenic.

Slides of the organism were then prepared, mounted and examined under a microscope. The organism's identity was confirmed to be $C$. destructivum by the aid of fungi identification manual by Barnett and Hunter (1995), annotated genera of Colletotrichum species by Damn et al.
(2009; 2014) and monographs of the International Mycological Institute IMI (1995).

\section{Preparation of spore suspension}

The spores of the pathogen $C$. destructivum were collected from 8-day old culture-agar stock in Petri dish by lifting $60 \mathrm{~cm}^{2}$ piece into a beaker containing $200 \mathrm{ml}$ of sterile distilled water. This was sieved through 4-folds of sterile cheesecloth to remove agar and mycelial mesh; and the filtrate was then centrifuged for 10 minutes. Thereafter the spores suspension was standardized using a hemocytometer counting slide to $10^{5}$ spores/ml (Awurum and Enyiukwu 2013b; Alberto 2019).

\section{Preparation of seedlings for the study}

Cowpea (Var. IAR: 48) seeds obtained from the Research and Training Unit of the College of Crop and Soil Sciences, were surface-sterilized in a $0.5 \%$ sodium hypochlorite solution for 1 minute, and rinsed in 3 changes of $200 \mathrm{ml}$ of sterile water. The seeds were sown 3 per 20 $\mathrm{cm}$ diameter plastic pot containing $4 \mathrm{~kg}$ heat-sterilized topsoil; and kept moist by light watering twice daily. At 8 days after sprouting, the seedlings were thinned to two per pot and remained so till 2 weeks after planting (WAP) when they were used for histological studies (Enyiukwu et al. 2018).

\section{Histological studies}

The method according to Latunde-Dada and Lucas (2007) was adopted for this study. Fresh uninfected leaves and stems were excised from the 2-week-old seedlings of cowpea (Var. IAR-48) as raised above; and inoculated on the surface (abaxial surface for the leaves) with four $3 \mu \mathrm{l}$ droplets of conidial suspension $\left(1.0 \times 10^{5}\right.$ spores $/ \mathrm{ml}$ of distilled water) (Vasic et al. 2014; Xie et al. 2019) of $C$. destructivum. The inoculated leaves and stems were incubated at $25^{\circ} \mathrm{C}$ in the dark chamber under humid conditions (Latunde-Dada et al. 1997). In the control experiment leaves and stems were treated with sterile deionized water in place of the conidial suspension of the fungus.

Pieces of the infected and healthy cowpea leaves and stems were cut after $72 \mathrm{~h}$ (1-4 day) intervals from the infection courts and de-colorized in a $0 \cdot 15 \%(\mathrm{w} / \mathrm{v})$ solution of trichloroacetic acid in a 3:1 (v/v) mixture of ethanol and chloroform for $12 \mathrm{~h}$. They were then stained in a $0.025 \%$ (w/v) solution of aniline blue in lactophenol for $2 \mathrm{~h}$ (Xie et al 2019). Light microscopic examinations were made on sections of the stained tissues with Olympus digital compound microscopic fitted with the software Scopevision (Version 9.0) camera and photographed. The photograph was taken of both healthy (uninfected) and diseased leaves and stems of cowpea infected with $C$. destructivum. 


\section{RESULTS AND DISCUSSION}

\section{Penetration and anatomical damage of cowpea leaf tissues by Colletotrichum destructivum}

The process of colonization and damage of cowpea leaf tissues by the $C$. destructivum is captured in Figures 2-5. The conidium of the test fungus which is hyaline, nonseptate, smooth-walled, ovoid, straight or slightly curved with more or less tapered ends (Figure 3), came in contact with and stuck on the cuticle of the leaf and germinated at 12 hai to produce germ tube, at the end of which it developed appressorium (Figure 3). Under this structure, it produced penetration peg which penetrated through the cuticle into a single epithelial cell; to form a multi-lobed somewhat spherical vesicle at about 48 hai (Figure 4.A-B). From this large primary structure thin multilateral hyphae developed at about 72 hai and initiated the tissue colonization (Figure 4.C-D) ramifying within the host tissue and subsequent production of the lesions ensued which was seen as the symptom of anthracnose disease of cowpea from 96 hai (Figure 4.E-F). The colonization of the tissues by the hyphae of the test fungus was both intercellular (Figure 5.A) and intra-cellular (Figure 5.B-C).

\section{Anatomical aberrations of cowpea stem tissues due to the test fungus}

The photomicrograph presented in Figure 6 shows comparative anatomical structures of healthy (uninfected) and infected cowpea stem with $C$. destructivum. The histological studies results indicated that the fungus strongly affected the integrity of stem tissues of the crop. All the cells of the healthy stem of the test cowpea (epithelial, cortical, vascular, and pith) were intact and well defined; they remained turgid and full of vitality, with the cementing middle lamella at the boundaries of the cells being clearly visible (Figure 6.A). In contrast, however, the activity of $C$. destructivum damaged the stem tissues of infected cowpea (Figure 6.B). The infected tissue cells were turbid and dispossessed of their vital nutrients during colonization of the pathogen, resulting in their distorted cell boundaries and lack of turgidity and vigor (Figure 6.B).

\section{Discussion}

Results of this study showed that conidia of the test fungus were hyaline, non-septate, smooth-walled, ovoidshaped, straight structures (Figure 3.A). This description tallies with those given by other workers who reported the same features for the fungus conidia with average dimension of $15 \times 4 \mu \mathrm{m}$ isolated from lucerne, alfalfa, and cowpea (Latunde-Dada et al. 1996; 1997; 1999. O'Connell et al. 2004). The results also showed that conidia upon contact with the host began to germinate at 12 hai and developed septum (Figure 3 B.a). This strongly agrees with the report of Latunde-Dada et al. $(1996 ; 1997)$ who noted that the conidia of the fungus conidia took $12 \mathrm{~h}$ to germinate and develop septum on cowpea and lucerne inoculated with the disease in Southwest, Nigeria. It also agrees with Shen et al. (2001) who reported that the conidia of the organism germinated on tobacco at about the same time. This, however, was earlier than 16 and 18 hai reported for $C$. capsici and $C$. lindemuthianum on pea and common bean respectively; but later than 4 and 6 hai for $C$. truncatum and $C$. dermatium on cowpea leaf and stem specimens (Smith et al. 1999). Similarly, that the germination time recorded for the conidia of the test pathogen in this study is at par with 12 hai reported for $C$. lindemuthianum on cowpea by Bailey et al. (1990) may suggest that both organisms might be the same fungus since $C$. lindemuthianum has been proven incapable of infecting cowpea (Latunde Dada et al. 1996; Adegbite and Amusa 2008; Akinbode and Amusa 2008 a,b; Enyiukwu et al. 2014; ASHC 2015).

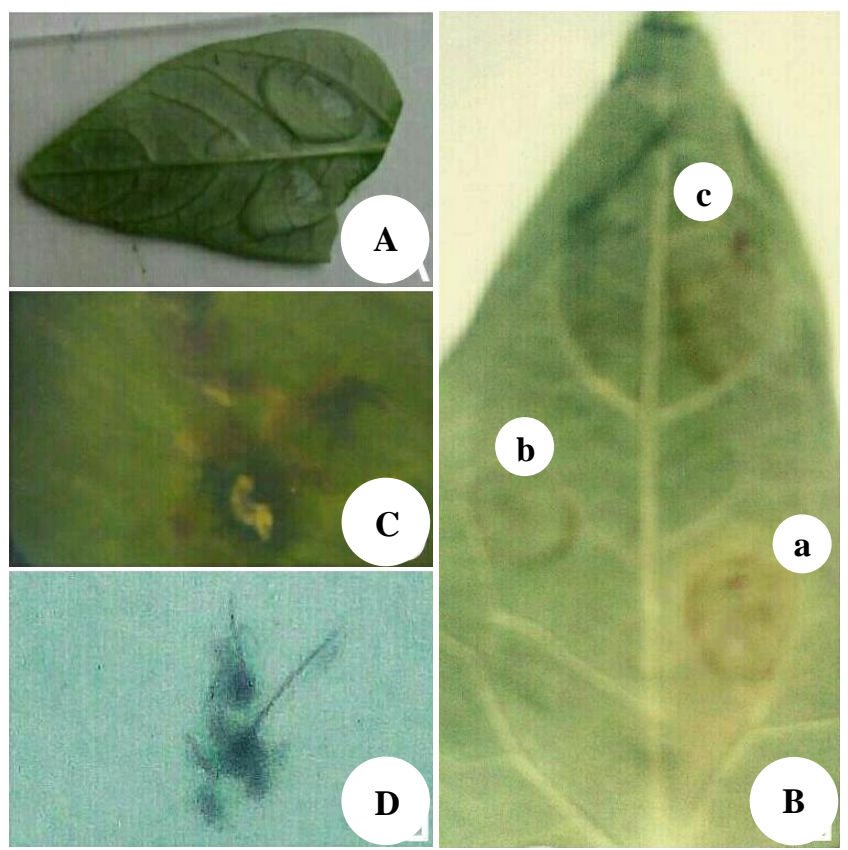

Figure 2. Photomicrograph of healthy (uninfected) and infected cowpea leaf tissues. (A) Healthy (uninfected) leaf inoculated with a drop $(0.05 \mathrm{ml})$ of inoculum at $0 \mathrm{~h},(\mathrm{~B})$ Appearance of necrotic spots on leaf 72 hai, (C) Mature lesion on leaf 96 hai, (D) Acervuli on lesion at $\geq 96$ hai. Magnification: $1 x$
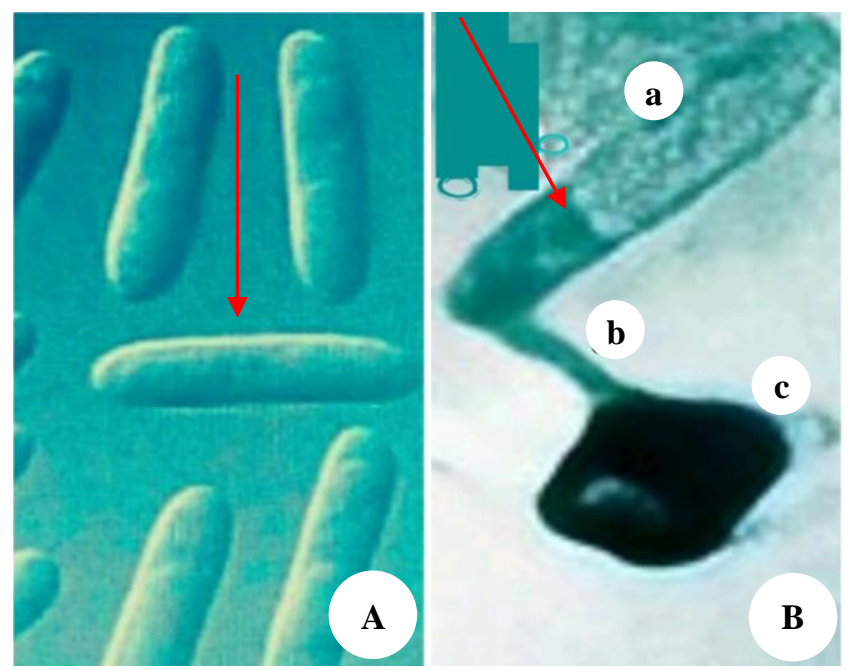

Figure 3. Conidium of Colletotrichum destructivum O'Gara, (A) Conidium at $0 \mathrm{~h}$ after inoculation on leaves (arrow = no septum observed), (B) Conidium at 12 Hai on cowpea leaf showing 
formation of germ tube and appressorium (arrow = septum observed). Magnification: 400x

At the pre-penetration stage, conidia (Figure 3A) and other propagules of plant pathogenic fungi secrete surface acting proteins (hydrophobins and integrins) with which they attach to the host and resist agitation (Tucker and Talbot 2001). The successful attachment of the test conidium in this study may have been due to these compounds. The germination of $C$. destructivum spores observed in this study was followed by the formation of germ tube, development of appressorium at the tip of the germ tube (Figure 3.Bc) from where penetration peg developed. This structure compromised and penetrated the host cuticle-epidermal layer directly within $24 \mathrm{~h}$. This is consistent with the report of many workers who reported direct penetration of the target hosts by Colletotrichum species (Da Silva et al. 2017; Xie et al. 2019). For instance, C. dermatium has been reported to penetrate cowpea (Smith et al. 1999) and $C$. destructivum also penetrated tobacco, lucerne and cowpea directly (Latunde-Dada et al. 1996; 1997; Shen et al. 2001). Many workers believe that this direct penetration was achieved through melaningenerated turgor pressure (Liao et al. 2012) assisted by hydrolyzing fungal cutinases (Pandey et al. 2012; Adelene et al. 2015) mustered to compromise certain phytoalexins (kievetone and phaseolidin of the plant defense system (Latunde-Dada and Lucas 2001). The tip of the infection peg remained and gradually enlarged inside the lumen of a single epidermal cell, forming large somewhat spherical vesicle which became multi-lobed and multi-septate at about 48 hai and gradually elongated to form the primary hyphae (Figure 4.A-B). The organism remained in this state till mid or late in the third day (about 72 hai). That the large primary hyphae remained inside a single epidermal cell for this length of time (72 hai) agrees with the characteristic transient localized biotrophy characteristic commonly demonstrated by members of $C$. destructivum sensu lato such as C. higginsianum, C. linicola, C. lentis, C. tabacum, and $C$. taneceti and $C$. horri on a variety of crops as reported by other workers (Shen et al. 2001; Barimani et al. 2013; O'Connell et al. 2014; Da Silva et al. 2017; Xie et al. 2019). However, it sharply contrasted with non-localized infection strategy of $C$. graminicola, $C$. falcatum and $C$. lindemuthianum on susceptible crop varieties where in the initial biotrophic phase many epidermal cells were invaded at once by their primary hyphae (Da Silva et al. 2017). Throughout this stage of biotrophy, the crop remained symptomless.

The primary hyphae that had formed and successfully established inside the epidermal cell at penetration, expanded to develop narrow filamentous secondary hyphae in all directions (Figure 4.C). The pathogen invaded adjacent epidermal and mesophyll cells late into the third day after inoculation. In a parallel study of C. obiculare causal agent of cucumber anthracnose; Qi et al. (2013) also noted formation of secondary hyphae from large constricted primary hyphae at this time on leaves of the crop. This leads to the appearance of chlorotic watersoaked necrotic spots on the test leaf surface at about 96 hai (Figure 4.C-D). Shen et al observed that the organism incited typical symptoms of the disease on tobacco at 96 hai. This is congruent with our observation in this study where the pathogen caused appearance of anthracnose lesions on the leaves of cowpea (Var. IAR-48) at 4 days after inoculation. However, our observation slightly deviated from the report of Latunde-Dada et al. (1996; 1997) who in a related study on lucerne and cowpea in Southwest Nigeria found typical symptoms of anthracnose to begin to emerge on the crops at 120 hai. The differences in the time of appearance of the symptoms of the disease may have been occasioned by differences in inoculum potentials of the strains of the pathogen in the regions, or differences in variety, stage of maturity of host plant, or prevailing environmental factors during the experiments.

The ability of the fungus to switch nutrition strategy from latent symptomless biotrophy to a damaging necrotrophy is triggered (or influenced) by changes in the synthesis and activity of cell wall degrading enzymes and secondary metabolites at the host plant-pathogen interface (Smith et al. 1999; Da Silva et al. 2017). The secondary hyphae is reported to secrete a diversity of cell-wallmacerating enzymes [polygalacturonase (PG), pectin lyase (PL), pectin methylesterase (PME), pectin methyl galacturonase (PMG), pectin transeliminase (PTE), carboxymethyl cellulose (CMC), etc.] which inactivate host anti-stressor peroxidases [superoxide dismutase (SOD), ascorbate peroxidase (APX), catalase (CAT), gluthatione peroxidase (GPX) in advance of their spread (Kumaran et al. 2013; Oliveira et al. 2014). With this army of enzymes, the fungal secondary hyphae rapidly attack, de-cement neighboring cell walls, and create expanding necrotic lesions (Figure 4.D) as they digest the tissues (Figure 4.E) (Qi et al. 2012; Plant Symbiosis 2015). Acervulus having a single-celled seta (a characteristic diagnostic feature of $C$. destructivum as against $C$. lindemuthianum that has multiple setae) developed on the surface of leaf lesion at 96 hai (Figure 2.C-D; Figure 4.F), thus completing the asexual cycle of the fungus. The production of only one seta on its acervulus by the test fungus in this study strongly conforms to submissions of production of only a single seta on the lesion of anthracnose-affected tobacco, lucerne and cowpea by $C$. destructivum (Latunde-Dada et al. 1996; 1997; Shen et al. 2001). Thus, the result of this study clearly showed a two-stage infection process - symptomless biotrophic nutrition (12-72 hai) and voraciously damaging necrotrophic nutrition (72- $\geq 96$ hai) - and as such the pathogen demonstrated a hemibiotrophic lifestyle. Inemibiotrophy is reported as a common lifestyle with some other members of the genera Colletotrichum such as C. trifolii, C. lindemuthianum as well as $C$. destructivum (Damm et al. 2009; 2014; Da Silva et al. 2017).

Results of the study presented in Figure 5 showed that the hyphae of $C$. destructivum macerated the affected cells both intra-cellularly and inter-cellularly; beginning first with degradation of the lumen of the initial single epidermal cell (Figure 5.A-B). Late in the infection process, the pathogenic hyphae compromised the cell walls and the cementing middle lamella as they enlongated and infected other epidermal and mesophyll tissues (Figure 5.C). 

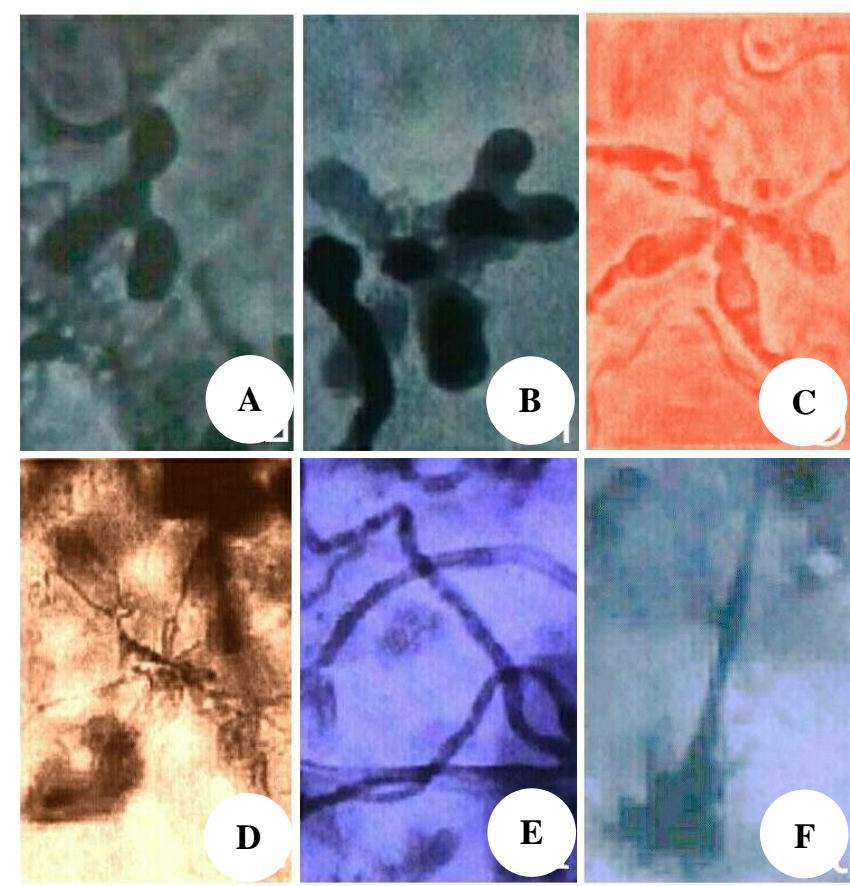

Figure 4. Infection process of Colletotrichum destructivum on cowpea. A-B. Fungal vesicle develops into multi-lobed structure 48 hai. C-D. Multi-lobed primary structure elongates into thinner secondary hyphae and ramifies neighboring epidermal cells with appearance of necrotic lesion on leaf 72 hai. E. Intercellular network of hyphae inside the cell at 96 hai. F. Acervulus on leaf lesion 96 hai. Magnification: 400x

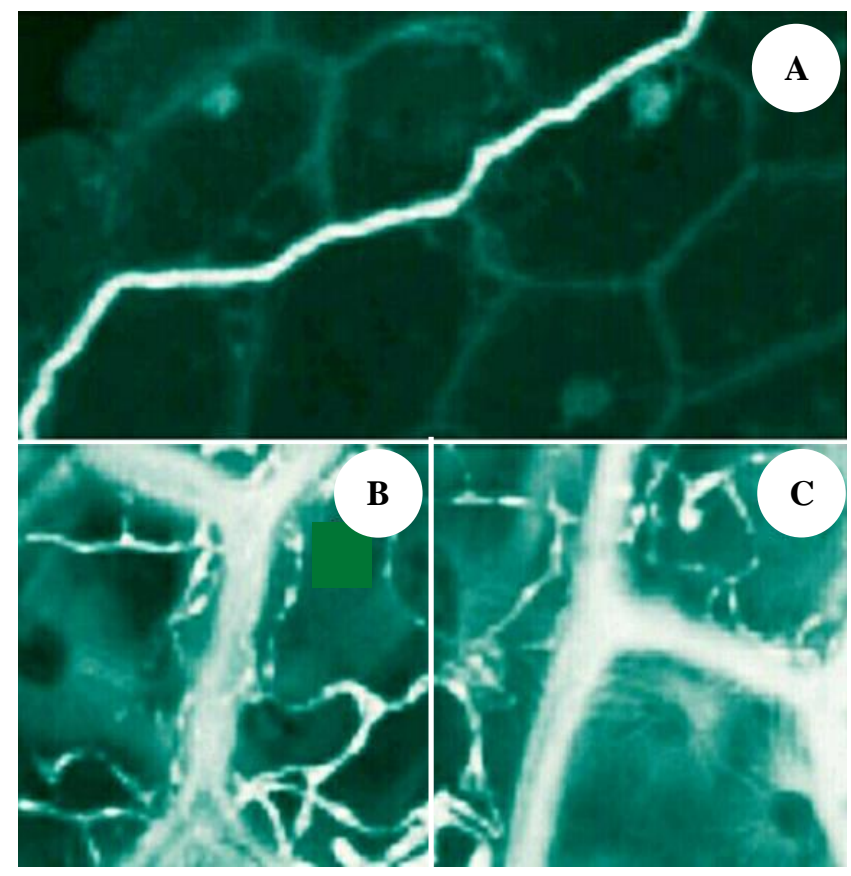

Figure 5. Photomicrograph of infected cowpea leaf tissue showing Intra-cellular and inter-cellular colonization by Colletotrichum destructivum. A. Intra-cellular hyphae in a cell during early infection by the pathogen. B. Infected and colonized cell with mass of intracellular hyphae of $C$. Destructivum. C. Intercellular hypha during late infection degrading along middle lamella of leaf tissues by the pathogen. Magnification: 400x
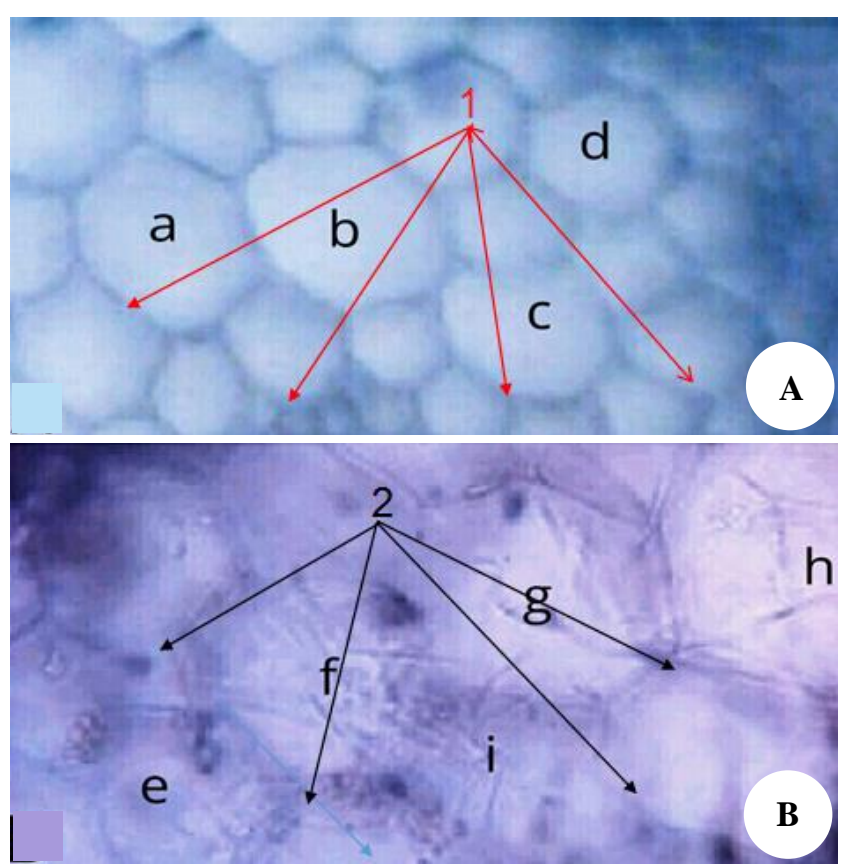

Figure 6. Photomicrograph of healthy (uninfected) and infected cowpea stem. A. Healthy (uninfected) cowpea stem tissue, a-d intact (undisrupted) cells, and 1 uncompromised cell boundaries. B. Infected cowpea stem tissue, e-i disrupted cells and 2 compromised cell boundaries of infected cells due to activities of C. Destructivum. Magnification: $400 \mathrm{x}$

This feature is consistent with the report of other workers such as Latunde-Dada et al. (1996; 1997), Shen et al. (2001) and Da Silva et al. (2017) who noted localized hemibiotrophy characterized by intra- and intercellular colonization as a prominent attribute of $C$. higginsianum, C. linicola, C. fuscum C. tabacum and C. destructivum which distinguishes them from $C$. graminicola, $C$. Sublineola, C. lindemuthianum and $C$. falcatum whose biotrophic strategy is non-localized. It was also noncongruent with the reported biotrophic phase of $C$. truncatum causal agent of anthracnose and brown blotch diseases of chilli pepper and cowpea respectively whose lifestyles are characterized by sub-cuticular intramural hemibiotrophy in both ferns and higher plants (Reboledo et al. 2015).

The study showed that the fungus as it ramified and colonized cowpea, depleted the crop of valuable growth factors of the crop as observed in the disparity in growth between the uninfected (control) stem (Figure 6.A) and the infected stem tissues (Figure 6.B). Unlike the uninfected control experiment (Figure 6.A), the infected tissues were turbid, and devoid of vitality, turgidity and vigor; and had weak and loose middle lamella compromised by fungal passage; and cleared, open spaces representing points of nutrient extraction, depletion, and degradation by the test fungus (C. destructivum) (Figure 6.B). This observation is in agreement with the findings of Amadioha (1994; 2012) and Markson et al. (2014) who also noted such points of nutrient degradation between tomato and potato tissues infected and colonized both inter- and intra-cellularly by 
Rhizopus stolonifer, Botrydiplodia theobromae, and Penicillium expansium than the control experiment.

In conclusion, this study clearly showed that the pathogen's infection process lasted $\geq 96$ hours hai; and demonstrated that the organism lives intra-cellular hemibiotrophic lifestyle. The first biotrophic phase lasted about 72 hai whereas it switched to a damaging necrotrophy in the later phase (72- $\geq 96$ hai). This later phase was attended by massive loss of tissue integrity and vitality. This complex lifestyle of Colletotrichum destructivum amongst other variables contributes to make managing cowpea anthracnose difficult. It is generally known that seeds remain a popular means of propagating cowpea. As such, they remain also a viable means of distributing seed-associated pathogen far and wide into disease-free locations. And given that Colletotrichum destructivum can potentially cross-infect hosts, all these, therefore, have far reaching implications for bio-security since $C$. destructivum can survive saprophytically on crop thrash and as spores on seed coats or endophytically as dormant mycelia on cotyledons. Again, being that the pathogen is very highly variable, available resistant varieties against the disease are not long-lasting. Understanding the lifestyle of the pathogen could contribute enormously towards developing proper diagnostics and tailoring appropriate control measures for the disease. Quarantining and strict control of trans-border trade in bean seeds is thus necessary and strongly recommended. Also, since the pathogen takes 3 days after infection to initiate and maintain biotrophic nutrition strategy before switching to a damaging necrotrophic phase; this implies that appropriate bio-pesticide or conventional fungicide must be applied at this point to achieve maximum control of the pathogen, increase yield and quality of cowpea, and lessen toxic chemical load on the environment.

\section{REFERENCES}

Adegbite AA, Amusa AN. 2008. The major economic field diseases of cowpea in the humid agro-ecologies of South-Western Nigeria. Afr J Biotechnol 7 (25): 4705-4712.

Adelene SMA, Ford R, Taylor PWJ. 2015. The role of cutinase and its impact on pathogenecity of Colletotrichum truncatum. Plant Pathol Microbiol 6 (3): 259-264

ASHC (African Soil Health Consortium). 2015. Anthracnose of cowpea Colletotrichum destructivum. http://african soilhealth.cabi.org/wpcms/wp-content/uploads/2015/02/7-legumesanthracnose-cowpea.pdf\&ved+2aU... Accessed November 30, 2020.

Akinbode AO, Ikotun T. 2008a. Evaluation of some bioagents and botanicals in in vitro control of Colletotrichum destructivum. Afr J Biotechnol 7 (7): 868-872.

Akinbode AO, Ikotun T. 2008b. Efficacy of certain plant extracts against seed-borne infection of Colletotrichum destructivum on cowpea (Vigna unguiculata). Afr J Biotechnol 7 (20): 3683-3685.

Alberto E. 2013. How to calculate the concentration of fungal spores suspension. www.researchgate.net/post/How_tocalculate_the_concentration_of_spores_fungal_... Accessed June 13 , 2020.

Amadioha AC, Enyiukwu DN. 2019a. Biochemical composition of seed and husk of cowpea (Vigna unguiculata L. Walp.) infected by Colletotrichum destructivum O'Gara in storage. Апnи Res Rev Biol 31 (1): 001-007.
Amadioha AC, Enyiukwu DN. 2019b. Alterations of biochemical composition of leaf and stem of cowpea (Vigna unguiculata L. Walp.) by Colletotrichum destructivum O'Gara in Nigeria. J Exp Agric Int 32(2): 001-007.

Amadioha AC. 1994. Pectolytic enzymes of Rhizopus arrhizus produced in culture and infected potato tubers. Fitopatol Brasilera 19: 139-143.

Awurum AN. 2013. Varietal screening and response of cowpea to some foliar diseases iand cropping systems n Southeast Nigeria. J. Sust. Agric. Environ. 14(1\&2): 59-78.

Bailey JA, Nash C, O’Connell RJ, Skipp RA 1990. Infection process and host specificity of a Colletotrichum species causing anthracnose disease of cowpea, Vigna unguiculata. Mycol. Res. 94: 800-804.

Barimani M, Pethybridge SJ, Vaghefi N, Hay FS, Taylor PWJ. 2013. A new anthracnose disease of pyrethrum caused by Colletotrichum tanaceti sp. nov. Plant Pathol 62 (6): 1248-1257.

Barnett HL, Hunter BB, 1995. Illustrated Genera of Imperfect Fungi ( ${ }^{\text {rd }}$ Ed). Burgress Publishing Co., Minneapolis.

Begum JMAJ, Venudevan B, Jayanthi M. 2013. Storage fungi in groundnut and the associated seed quality deterioration - A review. Plant Pathol J 12 (3): 127-134.

Begum MM, Sariah M, Puteh AB, Zainal-Adidin MA. 2008. Pathogenicity of Colletotrichum truncatum and its influence on soybean seed quality. Int J Agric Biol 10 (4): 393-398.

Begum MM, Saviah M, Puteh AB, Abidim MAZ. 2007. Detection of seed-borne fungi and site of infection by Colletotrichum truncatum in naturally infected soybean. J Agric Res 2 (9): 812-819.

Coates L, Cooke T, Forsberg 1. 2019. The biology and management of Colletotrichum diseases in production nurseries. Agric-Sci Queensland, Department of Agriculture and Forestry Ecosciences Precinct. In: Plant Health, Biosciences, Risk Management and Capacity Building. www.greenhousemag.com/gm/011colletotrighum-common-plant-disease...Accessed November 23, 2020.

Da Silva dos Crous PW, Ades PK, Hyde KD, Taylor PWJ. 2017. Life styles of Colletotrichum species and implication for plant biosecurity. Fungal Biol Rev 155-168. DOI: 10.1016/jfbn2017.05.001.

Damm U, Wonderberg JHC, Cannon PF, Crous PW. 2009. Colletotrichum species with curved conidia from herbaceous plants. Fungal Divers 45-88.

Damm U, O'Cornell RJ, Groenevald JR, Crous PW. 2014. Colletotrichum species complex, hemibiotrophic pathogens of forage and field crops. Stud Mycol 79: 31-84.

Enyiukwu DN, Amadioha AC, Ononuju CC. 2018. Significance of cowpea leaves for human consumption. Greener Trends Food Sci Nutr 1 (1): 001-010.

Enyiukwu DN, Awurum AN. 2013b. Comparative fungitoxicity of benomyl and extracts of Carica papaya roots and seeds and piper guineense seeds on Colletotrichum destructivum O"Gara. Continental J Biol Sci 6 (1): 38-42.

Enyiukwu DN, Awurum AN, Ononuju CC, Nwaneri JA. 2014. Biology and management strategies of cowpea anthracnose disease caused by Colletotrichum species. Greener J Biotechnol Biochem 1 (2): 052065.

Enyiukwu DN, Awurum AN. 2013a. Fungitoxic effects of Carica papaya and Piper guineense extracts against Colletotrichum destructivum in the glasshouse. Continental J Agric Sci 7 (1): 23-28.

Enyiukwu DN. 2017. Effects of extracts of some medicinal plants on Colletotrichum destructivum O'Gara causing anthracnose disease of cowpea (Vigna unguiculata L. Walp.) in Nigeria. [Doctoral dissertation, Dissertation]. Department of Plant Health Management, MOUAU, Nigeria.

Falade MJ, Enikuomehin OA, Borisade OA, Aluko M. 2018. Control of cowpea (Vigna unguiculata L. Walp.) diseases with intercropping of maize (Zea mays L.) and spray of plant extracts. J Adv Microbiol 7 (4): 001-010.

GPS (Global Positioning Systems) Coordinate. 2017. Google Play Store. www.google.com/gps...Accessed June 2018.

Guarnaccia L, Gilardi G, Martino I, GaribaldiA, Gullino L. 2019. Species diversity in Colletotrichum causing anthracnose of aromatic and ornamental Lamiaceae in Italy. Agronomy 9: 613. DOI: 10.103390/agronomy9100613.

IMI (International Mycological Institute), Kew, UK. 1995. Description of Pathogenic fungi and Bacteria Nos 316-317.

Kumaran RS, Yong-Keun C, Jeon HJ, Jung H, Kyung-Guen S, Kim HJ. 2013. In vitro antagonistic efficacy of plant extracts on the enzyme 
activity of Colletotrichum gloeosporioides. Afr J Microbiol Res 7 (12): 1069-1076.

Latunde-Dada AO, Bailey JA, Lucas JA. 1997. Infection process of Colletotrichum destructivum O'Gara from lucerne (Medicago sativa L.). Eur J Plant Pathol 103 (1): 35-41.

Latunde-Dada AO, Bailey JA, Lucas JA. 2001. The plant defense activator acibenzolar-S-methyl primes cowpea (Vigna unguiculata $\mathrm{L}$. Walp.) seedlings for rapid induction of resistance. Physiol Mol Plant Pathol 58 (5): 199-208. DOI: 10.1016/ppp.2001.0327.

Latunde-Dada AO, Lucas JA 1999. Stomatal penetration of cowpea (Vigna unguiculata) leaves by a Colletotrichum species causing latent anthracnose. Plant Pathol 48: 777-785.

Latunde-Dada AO, Lucas JO. 2007. Localized hemibiotrophy in Colletotrichum: Cytological and molecular taxonomic similarities among C. destructivum, C. linicola and C. truncatum. Plant Pathol 56 (3): 437-447.

Latunde-Dada AO, O’Cornell RJ, Nash C, Pring RJ, Lucas JA, Bailey JA. 1996. Infection process and the identity of the hemibiotrophic anthracnose fungus (Colletotrichum destructivum O'Gara) from cowpea (Vigna unguiculata L Walp.). Mycol Res 100: 1133-1141.

Lee HB, Kim CJ. 2002. First report of Colletotrichum destructivum on curly dock. Plant Dis 86: 1271. DOI: 1094/PDIS.2002.86.11.1271A.

Liao CY, Chen MY, Chen YK, Kuo KC, Ghung KR, Lee MH. 2012. Formation of highly branched hyphae by Colletotrichum acutatum within the fruit cuticle of Capsicum spp. Plant Pathol 61: 262-270.

Lobato AKS, Goncalves-Vidigal MC, Vidigal-Filho PS, Andrade CAB, Kvitschal MV, Bonato CM. 2010. Relationships between leaf pigments and photosynthesis in common bean plants infected by anthracnose. New Zealand J Crop Hortic Sci 38 (1): 29-37.

Markson AA, Omosun G, Umana EJ, Madonagu RE, Amadioha AC, Udo SE. 2014. Differential response of Solanum tuberosum L. and Ipomea batatas L. to three pathogens. Int J NatSci 2(1): 40-51.

Meyer S, Saccardy-Adji K, Rizza E, Gevity B. 2001. Inhibition of photosynthesis by Colletotrichum lindemuthianium in bean leaves determined by chlorophyll flourescence imaging. Plant Cell Environ 24: 947-985.

Miles TD, Gillett JM, Jarosz AM, Schilder AMC. 2013. The effect of environmental factors on infection of fruit by Colletotrichum acutatum. Plant Pathol 2013: 1-10. DOI: 10.1111/ppa.12061.

O'Connell R, Herbert C, Screenivasaprasad S, Khatib M, Esqurre-Tugaye M-T, Dumas B. 2004. A novel Arabidopsis-Colletotrichum pathosystem for molecular dissection of plant-fungal interactions. MPMI 17 (3): 272-282.

Ogu DE, Owoeye AE, 2013. In vitro control of anthracnose disease of cowpea (Vigna unguiculata L. Walp.) caused by Colletotrichum destructivum O'Gara with Cyathula prostata and Diodia scandens $\mathrm{Sw}$ leaf extracts. J Intercultural Ethnopharm 2 (1): 29-36

Oliveira JTA, Barreto ALM, Vasconcelos IM, Eloy YRG, Gondim DMF, Fernandes CF, Frier-Filho FR. 2014. Role of antioxidant enzymes, hydrogen peroxide and PR-proteins in the compatible and incompatible interactions of cowpea (Vigna unguiculata L. Walp.) genotypes with the fungus Colletotrichum gloeosporioides. J Plant Physiol Pathol 002-008.

Pandy A, Pandy BK, Muthukumar M, Yadava LP, Chauham UK 2012. Histological studies of infection process of Colletotrichum gloeosporioides Penz and Sacc. on Mangifera indica L. Plant Pathol. J. 11: 18-24.

Patel JS, Costa de Novaes MI, Zhang. 2014. First report of Colletotrichum higginsianum causing anthracnose of arugula (Eruca sativa) in Florida. Plant Dis 98 (9): 1269. DOI: 10.1094/PDIS-09-130926-PDN.

Plant Symbiosis Anonymous. 2015. Colletotrichum species - Medicinal plant archives. www.medicinal_plant_archive_us/plantsymbiosis/colletotrichum..., Retieved November 19, 2016.

Qi T, Hao C, Ma Q. 2013. Histological studies of Colletotrichum orbiculare on susceptible and resistant cucumber cultivars. Cucurbit Genet Cooperative Rep 25-26: 004-006.

Reboledo G, De Campos, R, Alvarez A, Montesano M, Mara H, De Leon IP. 2015. Physcomitrella patens activate defense responses against the pathogen Colletotrichum gloeosporioides. Int J Mol Sci 16: 22280-222298.

Sharma G, Maymon M, Freeman S. 2017. Epidemiology, pathology and identification of Colletotrichum including a novel species associated with avocado (Persea americana) anthracnose in Israel. Sci Rep 7: 15839. DOI: $10.1038 / \mathrm{s} 41598-017-11596-w$.

Shen S, Goodwin P, Hsiang T. 2001. Hemibiotrophic infection and identity of the fungus Colletotrichum, causing anthracnose of tobacco. Mycol Res 109 (11): 1340-1347.

Smith JE, Korsten L, Aveling TAS. 1999a. Infection process of Colletotrichum dematium on cowpea stems. Mycol Res 103 (2): 230234.

Smith JE, Korsten L, Aveling TAS. 1999b. Evaluation of seed treatments for reducing Colletotrichum dematium on cowpea seed. Seed Sci Technol 27 (2): 591-598.

Strivastava S, Strivastava M, Kumar R, Sinha A. 2013. Effect of seedborne mycoflora on the protein and amino acid contents of Jatropha carcus L. seeds during storage. Int J Plant Res 26 (2): 271-279.

Tucker SL, Talbot NJ. 2001. Surface attachment and pre-penetration stage development by plant pathogenic fungi. Annu Rev Phytopahol 39 (1): 385-417.

Vasic T, Bulajic A, Krnjaja VS, Jevremovic D, Zivkovic S, Andjelkovic B. 2014. First report of anthracnose on alfalfa caused by Colletotrichum linicola in Serbia. Plant Dis 98 (9): 1276. DOI: 10.1094/PDIS-03-14-0258-PDN.

Xie L, Zhang JZ, Cai L, Hyde KD, 2010. Biology of Colletotrichum horrri, causal agent of Persimmon anthracnose. Mycology 1 (4): 242253. 